\title{
PROMULGATION \\ OF THE MACROPRUDENTIAL REGULATION AND THE GUIDELINES FOR THE NBU MACROPRUDENTIAL POLICY
}

\begin{abstract}
Post-crisis spread of macroprudential regulation requires some generalizations and identification of the ways of adapting it to Ukraine. Current consensus about taxonomy and functionality of macroprudential toolkit is corresponded with empirical findings of potential efficiency of such instruments to restrain credit and assets price inflation. At the same time, macroprudential policy may be vulnerable to possibilities of large borrowing abroad and credit activity leakage on unregulated segments of financial system. In the paper it is noted that commodity rich economies constitute a specific profile there macroprudential policy is meant to diminish vulnerability to commodity prices volatility. Macroprudential instruments may help to restrain abnormal credit expansion in non-tradable sectors and bound sectoral credit concentration, thus opening new opportunities for sectoral policy. It is proved that macroprudential policy guidelines for National Bank of Ukraine should be determined by the specifics of implementing macroprudential policy in the environment of capital flows being influenced by the commodity prices, as well as by specific institutional distortions caused by oligarchical banking.
\end{abstract}

(C) Victor Kozyuk, 2018.

Kozyuk Victor, Doctor of Economic Sciences, Professor, Ternopil National Economic University, Ukraine. 


\section{Key words:}

Macroprudential policy, systemic vulnerability, financial system procyclicality, capital flows, commodity economies, leverage, capital buffers.

JEL: E58, E59, O23, Q33.

\section{Introduction}

Since the global financial crisis, a transformation of the financial stability policy has been occurring. It is characterized by a shift away from functional separation into monetary policy and micro-prudential policies. The latter has traditionally focused on ensuring the financial stability of individual financial institutions. The main reason for this is the growing importance of the financial system as the cause of macroeconomic fluctuations, economic imbalances and fiscal sustainability. Global integration and financial innovation have become a structural impetus to increase of the pro-cyclicality of the financial system, the emergence of its abnormal elasticity, and endogenous financial instability. The latter can be qualified as the self-actualization of stress phenomena on the basis of a combination of pro-cyclicality, financial boom, and the propagation of a spiral of financial imbalances. It results in a sudden, rapid and large-scale market correction developing in a crisis scenario that involves markets and companies in the form of a sharp contraction of liquidity, asset price collapse, bankruptcy, a jump of spreads, etc., combined with a change in the expectations of economic agents.

The usual microprudential approach did not always take into account the complexity of the links within the financial system, changes in attitude towards risk, as well as the accumulation of systemic risks that originate from the financial system itself, or are formed by cycles of global liquidity or structural features of the interaction of the national and global economies. For macroeconomic theory, the situation was quite similar. The so-called new Keynesian macro approach to monetary policy also ignored the problem of financial imbalances; in result a prudent central bank response to the accumulation of systemic macrofinancial risks was seen from the standpoint of introducing additional fluctuations in inflation and 
GDP, impairing the ability of economic agents to adequately interpret the actions of regulators. The clearing of markets after a financial shock appeared (and still seems to be to the majority of the followers of this approach) as a better alternative to "piercing» the bubbles. In addition, for countries in which the exchange rate plays a significant role in the monetary policy, macro-financial fluctuations accompanied by substantial cross-border capital flows create a major problem. The traditional increase in rates to slow down overheating of the economy may be accompanied by an inflow of capital. Raising the rate to neutralize the inflow of capital conversely may encourage external borrowing. In both cases, the prevailing situation in the global liquidity behaviour and attitude to risk determines the accumulation of systemic vulnerability of the financial sector beyond the restrictive monetary actions. This significantly reduces the ability of central banks to neutralize the effects of large-scale inflow of capital through standard decisions on interest rates, sterilization of reserves and exchange rates.

Given the limited capacity of micro-prudential regulation and monetary policy to ensure financial stability, the policy addressed to it evolved into a separate category. Many countries are actively introducing macroprudential policy focused on ensuring financial stability, monitoring and neutralizing systemic risks, easing the procyclicality of the financial system, limiting the endogenous tendency of the financial system to accumulate imbalances. The isolation of macroprudential regulation into a separate policy class has raised the question of its adequate tools, organizational design, coordination with other policies aimed at financial stability or wider macroeconomic processes. This raises the question of the guidelines of macroprudential regulation of the NBU and creates the need to identify the dominant features of central bank activity in this area.

\section{Theoretical foundations and methodological composition of the macroprudential approach: literature review}

The theoretical basis for the introduction of macroprudential regulation is the systematization and development of critical research in the field of financial imbalances. The main conclusion of the early research on this issue is, firstly, that price stability does not always guarantee financial stability, especially when monetary policy is trusted, and economic agents are prone to taking risks. Secondly, deflationary displacement and the fight against deflationary expectations lead to an overpriced liquidity offer from the central banks, aimed at maintaining nominal anchors of price stability, measured by the positive value of inflation. Thirdly, the financial system is pro-cyclical and endogenously unstable; credit 

and the Guidelines for the NBU Macroprudential Policy

expansion and asset price inflation develop based on soft liquidity policies and reflect the unwinding of the imbalances helix followed by a severe recession. Fourthly, the financial cycle is longer than the traditional business cycle, and therefore the temporal links between monetary and macrofinancial variables may fall outside the scope of monetary and microprudential policies. Moreover, monetary policy can be used to combat imbalances, but is often not enough, especially when raising interest rates provokes problems in the real sector. Consequently, a specialized policy addressing systemic risks will better address the growing threats to macroeconomic stability by the financial sector (Borio, White, 2004; Borio, 2006; Borio, 2006).

The separation of macroprudential policies into a separate class was also fuelled by serious criticism about whether monetary policy is capable of neutralizing financial imbalances without causing additional macroeconomic volatility. Most authors who subscribe to new Keynesianism emphasize that financial and price stability should be functionally separate and each of them should be addressed by the appropriate tool (Bernanke, Gertler, 1999; Svensson, 2016). Evidently, most contemporary discussions are about the question of optimal coordination of monetary and macroprudential policies and the problem of overlapping mandates, which does not exclude the former keeping the potential of interfering in the financial cycle (Svensson, 2016).

Most literary sources note that methodologically the macroprudential policy is based on taking interest rates or other market conditions that can be influenced by the central bank beyond the limits of specialized influence on financial variables. Instead, the use of direct measures that determine the ability to borrow or lend is foreseen. As a result, it is precisely because of this that there is an effect on the aggregated behaviour of macro-financial variables without directly involving interest rates. The development of the methodology of such instruments and the promotion of their adoption were approved at the Seoul G-20 Summit. Capital requirements based on Basel III also include the application of a macroprudential approach to countercyclical capital requirements. Expanding the experience of applying macroprudential regulation has allowed to differentiate the final and intermediate goals of financial stability policy, to allocate taxonomy of macroprudential instruments, to outline the understanding of transmission links within the framework of their application. It also gave an opportunity to identify empirical patterns of the consequences of introducing macroprudential measures, and to identify the problem of the institutional format of this policy in the context of coordination with other policies, etc. (Bayoumi, Dell'Ariccia, Habermeier, Mancini-Griffoli, Valencia, 2014; IMF-FSB-BIS, 2016; IMF, 2013; IMF, 2013; IMF,2013; CGFS, 2010).

Despite the fact that the empirical analysis of macroprudential policy is considered to be rather limited in time, the authors are largely unanimous about several conclusions. They include: the importance of the level of financial development for the effectiveness of macroprudential policy; the need to extend the 
scope of regulation to the para-banking sector; how the relevant instruments can influence the slowdown of credit boom and inflation of asset prices; higher efficiency of instruments oriented towards borrowers (especially households); the need to combine several tools at the same time to better address the diverse challenges in the financial sector, etc. At the same time, emerging markets have a more diverse experience of using macroprudential instruments, although they often disguise it in their tools for regulating capital flows (Claessens, 2014; Cerutti, Correa, Fiorentino, Segalla, 2016; Bruno, Shim, Song Shin, 2015; Cerutti, Claesens, Laeven, 2015; Carreras, Davis, Piggot, 2016; Cizel, Frost, Houben, Wierts, 2016). The latter are capable of generating systemic macrofinancial vulnerability in emerging markets, especially where there are inadequate financial systems and a high level of dollarization. Due to this, macroprudential regulation can be targeted at the manifestations of financial imbalances and systemic vulnerabilities that are generated by capital flows or, more broadly, by fluctuations in global liquidity (Bruno, Shim, Song Shin, 2015; Cerutti, Claessens, Laeven, 2015; Gulcin Ozkan, Filiz Unsal, 2014; Turner, 2016).

Resource-rich countries proved to be a separate line of research. Commodity economies often have a structure of a financial system that permits low efficiency of macroprudential instruments, since extractive sectors, which require significant capital investment, are oriented towards external borrowing (Kurronen, 2012). Nevertheless, a number of studies have shown that the tools of macroprudential regulation can reduce the vulnerability of the country's resources to macrofinancial fluctuations. This is because the flexible rate may not always be consistent with either the inflation targets or the goals of price competitiveness of non-extractive sectors. A stable rate, in turn, contributes to the accumulation of external debt and dollarization, and in case of accumulating a significant amount in foreign currency, the correction of the rate launches opposite transmission signals on the trade and financial channels of macroeconomic adaptation. Capital flows responding to fluctuations in world commodity prices can cause both the overheating of the financial sector and its cooling, though the use of the exchange rate will always be limited by the above considerations. The macroeconomic regulation potential is perceived in reducing the destructive influence on the financial sector of the commodity price fluctuations in the context of the link between the exchange rate and financial obligations. However, it is often difficult to make a clear distinction between the latter and the regulation of capital flows (Bruno, Shim, Song Shin, 2015; Cerutti, Claessens, Laeven, 2015; Gulcin Ozkan, Filiz Unsal, 2014; Turner, 2016).

Taking into account the increasing number of countries actively using the macro-prudential approach and the newly gained experience of its use, the question arises pertaining to the search for generalization of relevant practices and the formulation of guidelines for the implementation of macroprudential policy in Ukraine. The aim of the article is to show the formation of the research scope in this area with a special focus on the vulnerability associated with fluctuations in commodity prices. This will present a more structured look at the particular prob- 
lems of the domestic economy, help to identify specific areas of macrofinancial vulnerability and suggest benchmarks for the development of macroprudential regulation in Ukraine.

\section{Instrumental set of macroprudential policy and the growing importance of macroprudential regulation on the agenda of central banks}

The taxonomy of instruments of macroprudential policy rests on several points:

- $\quad$ systemic risks have a time dimension, that is, reflect the pro-cyclicality of the financial system, and cross-sectional dimension, that is, they show the nature of interconnections within the financial system, as well as the so-called ties between real and financial sector (real-financial links);

- systemic risks are actualized due to the fact that the financial system generates a number of external effects (externalities). These are the effects of strategic complementarity, fire sales and interconnectivity. The effects of strategic complementarity relate to strategic interactions between banks, other financial institutions and economic agents, resulting in the accumulation of systemic vulnerabilities and financial imbalances in the phase of the expansion of the financial cycle. The effects of fire sale of assets show a rapid price collapse due to the fact that most financial players have the same market position regarding financial instruments, which results in deterioration of their own state and the condition of other players, liquidity falls, and access to financing in the phase of compression is sharply limited. The effects of interconnectivity are caused by the shock propagations or financial contagions through the links between systemically important financial institutions and other market players (Claessens, 2014).

- the instrument specification differs depending on the phase of expansion of the financial system, the phase of compression, the spread of a contagion or shock propagation associated with systemically significant financial institutions;

- instruments are targeted at the capital of financial institutions, assets and liabilities (including borrowers) and liquidity.

Basic taxonomy of macroprudential instruments is described by the principle $3{ }^{*} 2$ (Table 1). However, there is no complete list of such tools. This is due to 
the fact that some of the existing regulatory tools can perform a dual function. For example, they can be used as tools of structural regulation, microprudential and macroprudential instruments at the same time. Required reserves, while initially a tool of monetary policy, is almost unanimously considered a macroprudential instrument as it is viewed as direct leverage on the aggregate supply of credit to the economy.

Table 1

Macroprudential instruments

\begin{tabular}{|c|c|c|}
\hline & Time dimension & Sectoral dimension \\
\hline Capital & $\begin{array}{l}\text { Countercyclical capital buffer } \\
\text { Dynamic provisioning } \\
\text { Sectoral capital requirements } \\
\text { Sectoral approach to weighing risks } \\
\text { Countercyclical leverage re- } \\
\text { quirements }\end{array}$ & $\begin{array}{l}\text { System risk buffers (SRB) } \\
\text { Capital buffers of systemically } \\
\text { important institutions }\end{array}$ \\
\hline Assets & $\begin{array}{l}\text { Loan-to-value cap (LTV) } \\
\text { Loan-to-income cap (LTI) } \\
\text { Debt-to-income cap (DTI) }\end{array}$ & $\begin{array}{l}\text { Restrictions on transactions with a } \\
\text { counter-agent (concentration limits) } \\
\text { Restricting a significant open po- } \\
\text { sition }\end{array}$ \\
\hline Liquidity & $\begin{array}{l}\text { Requirements for deposit-to-loan } \\
\text { coverage } \\
\text { Time-varying requirements for li- } \\
\text { quidity indicators } \\
\text { Time-varying requirements for } \\
\text { collateral in marginal lending }\end{array}$ & $\begin{array}{l}\text { Liquidity coverage ratio (LCR) } \\
\text { Net stable funding ratio (NSFR) } \\
\text { Minimum haircuts / margin floors } \\
\text { Minimal reserve requirements }\end{array}$ \\
\hline
\end{tabular}

The use of macroprudential instruments implies that some of them operate on a permanent basis, and some - depending on the nature of the financial cycle. A combination of different tools is designed to achieve a comprehensive effect.

Despite the experience of emerging markets, the specification of regulatory practices for the needs of macro-financial stability and the active introduction of macro-prudential regulation began after the global financial crisis. A significant impetus to the implementation of the specialized policy of financial stability is associated with the transition to Basel III, the decision of the Seoul G-20 Summit and the relevant activities of the IMF, the Bank for International Settlements, the Committee on Global Financial Stability, the Financial Stability Board, and Euro- 

and the Guidelines for the NBU Macroprudential Policy

pean and national bodies focused on the problem and systemic risks. In most cases, central banks are authorized to conduct macro-prudential regulation, although in some cases the mandate of maintaining financial stability with the help of appropriate tools is delegated to individual bodies. The main argument in favour of delegating the mandate for the implementation of macroprudential policy to the central banks is associated with the following facts. Central banks have inclusive data on the state of the financial system and individual financial institutions. Since macroprudential policies can affect the aspects pertaining to monetary and/or micro-prudential policies and vice versa, coordination between them will be facilitated in the event of their concentration within the framework of one agency. The main objection to this approach is the concentration of regulatory power. Delegation of the macroprudential functions to an agency affiliated with the Ministry of Finance is justified on the grounds that the burden of using macroprudential instruments has fiscal characteristics. At the same time, this approach has not become widespread. The advantage of central banks is explained by both the above-mentioned arguments and by their powers regarding the regulation of capital flows. For middle-income countries, this is still a question of the role of exchange-rate fluctuations and balance of payments in macrofinancial stability. For example, in the period of 2000-2013, out of 42 countries that started the transition to macroprudential regulation, 28 are low and middle-income countries, and 14 are developed countries. The distribution in the context of the applied tools is as follows (Table 2.).

\section{Table 2}

The use of macroprudential instruments, 2000-2013

\begin{tabular}{|l|c|c|c|}
\hline \multicolumn{1}{|c|}{ Type of tool } & $\begin{array}{c}\text { Total } \\
\text { countries }\end{array}$ & $\begin{array}{c}\text { Emerging } \\
\text { markets }\end{array}$ & $\begin{array}{c}\text { Developed } \\
\text { countries }\end{array}$ \\
\hline Loan-to value (LTV) & 24 & 13 & 11 \\
\hline Debt-to-income (DTI) & 23 & 16 & 7 \\
\hline Limits on credit growth (CG) & 6 & 6 & 0 \\
\hline Limits on foreign lending (FC) & 15 & 12 & 3 \\
\hline Reserve requirements (RR) & 10 & 10 & 0 \\
\hline Dynamic provisioning (DP) & 7 & 6 & 1 \\
\hline $\begin{array}{l}\text { General Countercyclical Capi- } \\
\text { tal Buffer (CTC) }\end{array}$ & 5 & 2 & 3 \\
\hline Total classified by countries & 42 & 28 & 14 \\
\hline
\end{tabular}

Source: (Claessens, 2014). 
Regarding the nature of the use of macroprudential instruments, an example of a sample of 64 countries (Cerutti, Correa, Fiorentino, Segalla, 2016) found: in most cases, they were focused on creating stricter conditions. The number of episodes with loosening conditions is higher than that with tightening conditions only regards to the required reserves (Table 3 ).

\section{Table 3}

The direction of macroprudential policy in the context of 64 countries over the past 15 years

\begin{tabular}{|l|c|c|c|}
\hline & $\begin{array}{c}\text { Number } \\
\text { of countries with } \\
\text { episodes } \\
\text { of using the tool } \\
\text { to tighten the } \\
\text { conditions }\end{array}$ & $\begin{array}{c}\text { Number } \\
\text { of countries with } \\
\text { episodes } \\
\text { of using the tool } \\
\text { to loosen the } \\
\text { conditions }\end{array}$ & $\begin{array}{c}\text { Number } \\
\text { of countries } \\
\text { using the tool }\end{array}$ \\
\hline $\begin{array}{l}\text { Sector specific capital } \\
\text { buffers (SSCB) for real } \\
\text { estate loans }\end{array}$ & 20 & 9 & 64 \\
\hline $\begin{array}{l}\text { Sector specific capital } \\
\text { buffers (SSCB) for } \\
\text { consumer loans }\end{array}$ & 7 & 3 & 64 \\
\hline $\begin{array}{l}\text { Sector specific capital } \\
\text { buffers (SSCB) for } \\
\text { other loans }\end{array}$ & 11 & 3 & 64 \\
\hline Concentration limits & 21 & 2 & 36 \\
\hline Interbank exposures & 13 & 1 & 22 \\
\hline RR foreign currency & 20 & 17 & 64 \\
\hline RR local currency & 29 & 44 & 64 \\
\hline $\begin{array}{l}\text { Loan-to-value limits } \\
\text { (LTV) }\end{array}$ & 33 & 14 & 38 \\
\hline $\begin{array}{l}\text { General capital re- } \\
\text { quirements }\end{array}$ & 55 & 0 & 57 \\
\hline
\end{tabular}

Source: (Cerutti, Correa, Fiorentino, Segalla, 2016).

At the same time, a formal assessment of whether a country uses macroprudential instruments is limited. The unestablished nature of the instrumental set of financial stability policy creates a situation where, for example, microprudential instruments are specified for use with a macroprudential purpose. The same ap- 

and the Guidelines for the NBU Macroprudential Policy

plies to instruments that regulate capital flows and address the problem of the different currency structure of assets and liabilities both in the financial and real sectors. Ukraine is not an exception here. Although a relatively steady set of tools (Table. 1) is expected to be used in the next few years, the index that measures the intensity of the implementation of macroprudential policy is sufficiently high for Ukraine, which puts it on par with the leaders of the transition to this type of policy (Cerutti, Claesens, Laeven, 2015). However, this is a reflection of the fact that the use of tools that regulate capital flows, open position and limit the gap in the currency structure of assets and liabilities can be interpreted from the macroprudential point of view.

\section{Evaluations of the effectiveness of using macroprudential instruments: general and raw material context}

Despite the relatively short period of macroprudential policy implementation, most studies indicate its effectiveness. In this case, efficiency is understood not so much as the total ability to minimize the likelihood of financial crises or financial shocks, but as an ability to influence the behaviour of variables associated with the accumulation of imbalances and systemic vulnerabilities. Based on numerous studies it was found that such variables are internal credit, asset prices, level of leverage and the magnitude of the burden of interest payments in relation to borrowers' income. The first two indicators are generally highlighted as the most representative indicators of the financial instability lag, which are also correlated with the deterioration of the balance of payments, the real revaluation of the national currency and the inflow of capital, provoking overheating of the financial sector. A more complex approach involves the use of wider comprehensive indicators - financial conditions indices, financial vulnerability indices, and financial stress indices. They paint a larger picture of the financial system's ability to «create» a unit of solvency. However, for the most part they are used for analytical purposes. The main addressing of macroprudential policies is realized through monitoring of systemic risk, generated by the deviation of the domestic credit / asset prices from the medium-term trajectory. Most of the empirical studies chose precisely these indicators as an independent variable. The generalization of relevant research is mostly unanimous about the effectiveness of macroprudential instruments, but the need for them is growing.

The results of empirical assessments of the effectiveness of macroprudential policy generally confirm the hypothesis that a separate policy of financial stability is capable of influencing the behaviour of variables with which it is associated, thereby laying the preconditions for the functional separation from the 
monetary policy. In essence, this means that the setting of interest rates can cease being responsible for financial stability. However, this assumption would be rather too radical and optimistic. One of the first studies of the macroprudential policies' effectiveness on the example of Spain has shown that macroprudential instruments used by the Bank of Spain influenced the slowdown of asset price inflation and credit boom constraints overall, but did not prevent a largescale banking crisis linked to the reversal of macro-financial imbalances in the euro area (Jimenez,Ongena, Peydro, Saurina Salas, 2012).

While the case of Spain is special and characterized by a number of nuances associated with the peculiarities of the spread of imbalances in the currency union, in general, the results of empirical studies are the following.

Firstly, macro-prudential policy is effective, but just how effective it is depends on the nature of the economy and the level of financial development (Cerutti, Claessens, Laeven, 2015).

The more financially open the economy and the more developed the financial sector in it, the less pronounced is the ability of macroprudential instruments to influence asset prices and the dynamics of domestic credit. This is due to the alternative ways of accessing funding. It is also connected to the level of development of the financial system. It substantially affects the ability to meet customers' financing needs. In addition, the phase of the global financial cycle is also significant. In the case where global liquidity expansion significantly influences the attitude to risk, the possibility of circumventing the standard macroprudential limitations increases. This is especially true of the ability to direct external borrowing in the banking and real economy sectors. However, in countries that are not sufficiently financially open, the possibilities for such manoeuvres significantly expand. The same applies to the shallow financial systems.

Secondly, the quantitative restrictions that characterize macroprudential instruments (as opposed to the prices that are characterized by monetary instruments) are effective before the substitution effect comes into play (Cizel, Frost, Houben, Wierts, 2016).

In the event that a so-called shadow banking system can take over the generation of loan offers, imposing restrictions on the expansion of loan offers generated by traditional banking may not be sufficiently effective. This raises the question of the scope of macro-prudential regulation, as well as the set of tools. In the first case, the extension of such regulation to the para-bank system will weaken the substitution effect, but cause a number of difficulties with the powers of the regulator. Central banks do not always have the competence to regulate the para-banking sector. As for the instruments, even after the expansion of the regulation scope by incorporating the shadow banking system, standard instruments may be limited due to the non-standard nature of the process of liquidity transformation by para-bank intermediaries and nuances with financial contracts. The same applies to regulatory capital requirements. 

and the Guidelines for the NBU Macroprudential Policy

Thirdly, the relative effectiveness of any given macroprudential instrument remains uncertain.

For example, most of the instruments addressed to borrowers (LTV, DTI, $\mathrm{LTI}$, etc.) are effective in the event of a boom in real estate prices. By limiting the volume of loans directed to this sector and limiting the possibility of increasing debt among borrowers, these tools help to reduce the level of systemic vulnerability of the financial system to fluctuations in asset prices (Cerutti, Correa, Fiorentino, Segalla, 2016; Cerutti, Claessens, Laeven, 2015; Carreras, Davis, Piggot, 2016). However, in the case of a more general trend towards credit expansion, they may not be sufficiently effective. The same applies to instruments targeted at regulating capital. In the context of a lumbering boom in a separate sector, additional counter-cyclical capital requirements may turn out to be limited in efficiency or even redistributive. The high profitability of the financial sector can also reduce the efficiency of this class of instruments. From this it follows that the most effective macroprudential policy can be implemented when there is a combination of several tools (as needed) and when there is a comprehensive analysis of financial conditions and vulnerability to shocks.

Fourthly, a significant role of the exchange rate in maintaining financial stability is potential grounds for the effective application of macroprudential reguIation (Bruno, Shim, Song Shin, 2015; Cerutti, Claessens, Laeven, 2015; Gulcin Ozkan, Filiz Unsal, 2014; Turner, 2016).

In the case of a country facing shocks of capital flows, but limited in its ability to absorb significant exchange rate volatility, macroprudential instruments can smooth the conflict between domestic goals and the exchange rate. Such tools allow the user to restrict the overheating of the domestic financial sector and keep the rate from excessive revaluation. The latter is extremely important because the upward correction does not always limit the flow of capital or slow down aggregate demand, as the standard macroeconomic model predicts. In the case of risk behaviour in global markets, the upward movement of the rate is not limited by cross-border flows of bank capital. Similarly, this applies to borrowings of residents in foreign currency. Moving up the rate may signal the relative depreciation of such borrowing increases the leverage in foreign currency. Together, this means that the stimuli for the economy associated with the financial channel of the exchange rate may be opposite to the constraints of the trading channel, thereby setting the prerequisites for the systemic vulnerability of the financial system. Macroprudential policy has sufficiently limited excessive borrowing in dollarized economies, thereby weakening their vulnerability to exchange rate fluctuations.

Fifth, macroprudential policy can limit the destructive impact of the global financial cycle (Turner, 2016).

The hypothesis of the global financial cycle implies that, since attitude towards risk is an attributable feature of global financial conditions, the exchange 
rate regime is no longer a guarantee of neutralizing the influence of exogenous factors on the national economy, and therefore only regulatory instruments can remedy the situation. Thus, the trilemma becomes a dilemma. Despite the fact that this idea is often criticized, it reflects a significant vulnerability of a small open economy, which may cause a significant decline in long-term interest rates regardless of the ability of the central bank to control the short-term ones. The sloping yield curve is often seen as one of the signs of accumulating systemic vulnerabilities in the financial system. In the case where such a profile of the yield curve is shaped by global factors, monetary policy becomes extremely limited in its ability to influence internal financial conditions (the so-called Greenspan's Conundrum). This opens up space for macroprudential regulation. A number of papers (2015) confirm the ability of macroprudential instruments to limit the impact of capital flows on domestic asset prices, domestic credit and leverage (Bruno, Shim, Song Shin, 2015; Zhang, Zoli, 2014). At the same time, macro-prudential policy allows more effective combating financial overheating than monetary, in the case when the latter is due to the influx of capital. The first will be more successful if it is supported by a synchronous tighter monetary policy. However, in some cases (Bruno,Shim, Song Shin, 2015) the delineation of macroprudential policy and the policy of restrictions on capital flows is merely nominal. On the one hand, this does not allow assessing the effectiveness of standard macroprudential instruments in their pure form. On the other hand, it is emphasized that often for a small open economy, the boundary between the instruments of both policies is conditional, and adaptation to large-scale fluctuations of global liquidity requires non-standard decisions.

Sixthly, commodity economies are a special case of a small open economy, where macroprudential policies must take over a significant part of the responsibility for macro-financial stability.

With the development of the financial sector and the deepening of the domestic commodity market, fluctuations in export prices are accompanied by capital flows, the impact of which on the heating of domestic lending and asset prices cannot always be offset by counter-cyclical fiscal buffers (sovereign wealth funds) or currency reserves. In addition to the traditional dilemmas of choosing between exchange rate flexibility and fluctuations in the real effective exchange rate (a more stable rate leads to inflation fluctuations in the event that trade shocks are not completely offset by fiscal policies or when sterilization of reserves is limited), attempts to curtail the revaluation of currency are tempered by structural considerations. In other words, commodity economies need both to neutralize the negative effects of reversals in large-scale capital flows caused by shocks in commodity prices, and to prevent the «Dutch disease». Macroprudential policy should play a key role in weakening the link between the cycle of commodity prices and domestic financial cycle (Turner, 2016; Masson, 2014; Alberola, Benigno, 2017; Gonzalez, Hamann, Rodriguez, 2015; IMF, 2015). In general, it can be argued that commodity economies require a more complex mix of policies (see Table 4). 
Table 4

The channels of macrofinancial vulnerability of commodity economies and the effectiveness of macroeconomic regimes

\begin{tabular}{|c|c|c|c|c|c|}
\hline $\begin{array}{l}\text { Vulne- } \\
\text { rability } \\
\text { channels }\end{array}$ & $\begin{array}{l}\text { Fixed } \\
\text { rate. In- } \\
\text { depend- } \\
\text { ence of } \\
\text { the cen- } \\
\text { tral bank } \\
\text { is not im- } \\
\text { portant }\end{array}$ & $\begin{array}{l}\text { Fixed rate }+ \\
\text { «intertemporal } \\
\text { savings». In- } \\
\text { dependence of } \\
\text { the central } \\
\text { bank is not } \\
\text { important, } \\
\text { government is } \\
\text { dominant }\end{array}$ & $\begin{array}{l}\text { Monetary } \\
\text { regimes } \\
\text { with floating } \\
\text { rates. Inde- } \\
\text { pendence } \\
\text { of the cen- } \\
\text { tral bank is } \\
\text { important }\end{array}$ & $\begin{array}{l}\text { Monetary } \\
\text { regimes } \\
\text { with floating } \\
\text { rates + «in- } \\
\text { tertemporal } \\
\text { savings». } \\
\text { Independ- } \\
\text { ence of the } \\
\text { central bank } \\
\text { is important }\end{array}$ & $\begin{array}{c}\text { Monetary re- } \\
\text { gimes with } \\
\text { floating rates + } \\
\text { «intertemporal } \\
\text { savings» + } \\
\text { macropruden- } \\
\text { tial instru- } \\
\text { ments. Inde- } \\
\text { pendence of } \\
\text { the central } \\
\text { bank is essen- } \\
\text { tial }\end{array}$ \\
\hline $\begin{array}{l}\text { Terms of } \\
\text { trade shock } \\
\text { transferred } \\
\text { to sover- } \\
\text { eign sol- } \\
\text { vency }\end{array}$ & $\begin{array}{l}\text { Does not } \\
\text { solve the } \\
\text { problem }\end{array}$ & $\begin{array}{l}\text { Helps to better } \\
\text { adapt to the } \\
\text { new equilib- } \\
\text { rium condi- } \\
\text { tions }\end{array}$ & $\begin{array}{l}\text { Offsetting } \\
\text { the terms of } \\
\text { trade shock } \\
\text { does not } \\
\text { guarantee } \\
\text { improved } \\
\text { solvency in } \\
\text { the short- } \\
\text { term period }\end{array}$ & $\begin{array}{l}\text { Better adap- } \\
\text { tation to } \\
\text { new equilib- } \\
\text { rium condi- } \\
\text { tions is ac- } \\
\text { companied } \\
\text { by higher } \\
\text { price stabil- } \\
\text { ity }\end{array}$ & - \\
\hline $\begin{array}{l}\text { External } \\
\text { debt of cor- } \\
\text { porations }\end{array}$ & $\begin{array}{l}\text { Problem } \\
\text { amplifier }\end{array}$ & $\begin{array}{l}\text { Not always a } \\
\text { guarantee of } \\
\text { excessive bor- } \\
\text { rowing }\end{array}$ & $\begin{array}{l}\text { Exposure to } \\
\text { risk }\end{array}$ & $\begin{array}{l}\text { Allows for } \\
\text { lower volatil- } \\
\text { ity economy }\end{array}$ & $\begin{array}{l}\text { Improves the } \\
\text { situation and } \\
\text { limits the risks } \\
\text { of structural } \\
\text { transformation }\end{array}$ \\
\hline $\begin{array}{l}\text { External } \\
\text { debt of } \\
\text { banks }\end{array}$ & $\begin{array}{l}\text { Problem } \\
\text { amplifier }\end{array}$ & $\begin{array}{l}\text { Not always a } \\
\text { guarantee of } \\
\text { excessive bor- } \\
\text { rowing }\end{array}$ & $\begin{array}{l}\text { Vulnerable } \\
\text { to the atti- } \\
\text { tude to risk }\end{array}$ & $\begin{array}{l}\text { Allows for } \\
\text { lower volatil- } \\
\text { ity economy }\end{array}$ & $\begin{array}{l}\text { Improves the } \\
\text { situation }\end{array}$ \\
\hline $\begin{array}{l}\text { Leveraging } \\
\text { non-export } \\
\text { sectors }\end{array}$ & $\begin{array}{l}\text { Problem } \\
\text { amplifier }\end{array}$ & $\begin{array}{l}\text { May be effec- } \\
\text { tive only under } \\
\text { the condition } \\
\text { of a restrictive } \\
\text { policy on the } \\
\text { growth of do- } \\
\text { mestic reve- } \\
\text { nues }\end{array}$ & $\begin{array}{l}\text { Does not } \\
\text { solve the } \\
\text { problem }\end{array}$ & $\begin{array}{l}\text { Does not } \\
\text { guarantee } \\
\text { avoiding the } \\
\text { problem }\end{array}$ & $\begin{array}{l}\text { Improves the } \\
\text { situation }\end{array}$ \\
\hline $\begin{array}{l}\text { Asset } \\
\text { prices }\end{array}$ & $\begin{array}{l}\text { Problem } \\
\text { amplifier }\end{array}$ & $\begin{array}{l}\text { Does not solve } \\
\text { the problem }\end{array}$ & $\begin{array}{l}\text { Does not } \\
\text { solve the } \\
\text { problem }\end{array}$ & $\begin{array}{l}\text { Does not } \\
\text { guarantee } \\
\text { avoiding the } \\
\text { problem }\end{array}$ & $\begin{array}{l}\text { Improves the } \\
\text { situation }\end{array}$ \\
\hline
\end{tabular}




\begin{tabular}{|c|c|c|c|c|c|}
\hline $\begin{array}{l}\text { Vulne- } \\
\text { rability } \\
\text { channels }\end{array}$ & $\begin{array}{l}\text { Fixed } \\
\text { rate. In- } \\
\text { depend- } \\
\text { ence of } \\
\text { the cen- } \\
\text { tral bank } \\
\text { is not im- } \\
\text { portant }\end{array}$ & $\begin{array}{l}\text { Fixed rate }+ \\
\text { «intertemporal } \\
\text { savings». In- } \\
\text { dependence of } \\
\text { the central } \\
\text { bank is not } \\
\text { important, } \\
\text { government is } \\
\text { dominant }\end{array}$ & $\begin{array}{l}\text { Monetary } \\
\text { regimes } \\
\text { with floating } \\
\text { rates. Inde- } \\
\text { pendence } \\
\text { of the cen- } \\
\text { tral bank is } \\
\text { important }\end{array}$ & $\begin{array}{l}\text { Monetary } \\
\text { regimes } \\
\text { with floating } \\
\text { rates + «in- } \\
\text { tertemporal } \\
\text { savings». } \\
\text { Independ- } \\
\text { ence of the } \\
\text { central bank } \\
\text { is important }\end{array}$ & $\begin{array}{c}\text { Monetary re- } \\
\text { gimes with } \\
\text { floating rates + } \\
\text { «intertemporal } \\
\text { savings»+ } \\
\text { macropruden- } \\
\text { tial instru- } \\
\text { ments. Inde- } \\
\text { pendence of } \\
\text { the central } \\
\text { bank is essen- } \\
\text { tial }\end{array}$ \\
\hline $\begin{array}{l}\text { Relation- } \\
\text { ship be- } \\
\text { tween cor- } \\
\text { porate and } \\
\text { sovereign } \\
\text { solvency }\end{array}$ & $\begin{array}{l}\text { Problem } \\
\text { amplifier }\end{array}$ & $\begin{array}{l}\text { Limited effec- } \\
\text { tiveness }\end{array}$ & $\begin{array}{l}\text { Does not } \\
\text { solve the } \\
\text { problem }\end{array}$ & $\begin{array}{l}\text { Does not } \\
\text { guarantee } \\
\text { avoiding the } \\
\text { problem }\end{array}$ & $\begin{array}{l}\text { Improves the } \\
\text { situation along } \\
\text { with significant } \\
\text { fiscal space }\end{array}$ \\
\hline $\begin{array}{l}\text { Dollariza- } \\
\text { tion of li- } \\
\text { abilities }\end{array}$ & $\begin{array}{l}\text { Problem } \\
\text { amplifier }\end{array}$ & $\begin{array}{l}\text { Does not solve } \\
\text { the problem }\end{array}$ & $\begin{array}{l}\text { It may } \\
\text { worsen the } \\
\text { situation in } \\
\text { case of un- } \\
\text { predictable } \\
\text { changes in } \\
\text { price trends }\end{array}$ & $\begin{array}{l}\text { Does not } \\
\text { solve the } \\
\text { problem }\end{array}$ & $\begin{array}{l}\text { Improves the } \\
\text { situation }\end{array}$ \\
\hline
\end{tabular}

Note 1. The regime of «intertemporal savings» refers to a hybrid policy for the accumulation of foreign exchange reserves by a central bank, wherein it performs not only the monetary role, but also the role of the quasi-fund of sovereign wealth, as well as the creation of fiscal buffers that can be qualified as funds of sovereign wealth, excepting so-called guarantee funds of future retirement benefits.

At the same time, the specification of macroprudential instruments for the needs of financial stability in a commodity economy causes a number of difficulties. The effectiveness of the instruments applied to borrowers can play a positive role if a positive shock to commodity prices is converted into an expected increase in income that is considered a guarantee of future debt payments. At the same time, it should be borne in mind that in the commodity economies, moving credit resources to the non-export sector, for example construction of real estate, has long-term negative structural impacts. Increased leverage in the non-export and household sectors reinforces the negative Balassa-Samuelson effects; does not prevent, but amplify "Dutch disease», and makes the financial system highly vulnerable to commodity prices reverse. Thus, in the case of persistent positive terms of trade shock, macroprudential instruments directed at borrowers may not work if there is an equal trajectory of increasing revenues. Limits on the concen- 

and the Guidelines for the NBU Macroprudential Policy

tration of lending in one or two sectors can have a positive effect in combination with other measures. Restrictions on lending to the raw materials sector coupled with the real estate sector can help. However, such restrictions are unlikely to be effective alone, aside from the particular structure of the financial system in commodity economies, which can be dominated by large external borrowing of large companies. If external borrowing in the financial and real sector is more applicable to companies have concentrated raw material assets, ensuring financial stability will require a tighter link between macroprudential instruments and instruments addressed to capital flows. The same is true for discrepancy in the currency structure of assets and liabilities. Significant external borrowings in the phase of rising commodity prices may affect the effectiveness of counter-cyclical instruments if they are oriented exclusively towards residents, even if a positive raw material shock does not directly affect the expectations of the future revenues. Specific conditions for the functioning of commodity economies require a more comprehensive approach in the field of macroprudential policy. It should provide for the immediate use of a large set of relevant instruments, and the boundary between them and the instruments for regulating capital flows is rather blurry.

\section{Guidelines for the macroprudential policy of the NBU}

Ukrainian economy has demonstrated a number of characteristic episodes that were fully within the definition of systemic risks and resulted in deep financial and bank turmoil in 2008-2009 and 2014-2015. Its structural characteristics also indicate the need to supplement the standard division into monetary and microprudential policy with a «profile» policy aimed at financial stability in its macroeconomic dimension. Chronologically the most sufficient reasons to introduce a more comprehensive macroprudential approach formed in 2005-2008, as well as 2010-2013. The lack of adequate counter-cyclical policies has affected the 2014-2015, and it was characterized by systemic financial instability. It was accompanied by profound institutional distortions in addition to standard macrofinancial issues. Associated lending, the increasing importance of the offshore component in the cash flows of financial and industrial groups, and the manipulation over the assessments of the loan quality combined with the total reluctance to increase the capitalization of banks by owners, gave rise to significant systemic risks, which cannot always be addressed by standard macroprudential tools. Despite this, the domestic banking system continues to preserve the signs of structural vulnerability, the prevention of which will be addressed by the implementation of the macroprudential policy of the NBU. 
In line with the changes taking place in the approaches to the functioning of modern central banks and taking into account the recommendations of the Basel Committee on Banking Supervision, the European Systemic Risk Board, the EU Directives on capital requirements, the National Bank of Ukraine started work on implementing the objective of promoting financial stability, defined by art. 6 of the Law of Ukraine on the National Bank of Ukraine. One of its forms is the elaboration and implementation of the NBU macroprudential policy strategy, which provides for the introduction of a number of relevant instruments, the activation of some of which will begin in 2019. The creation of the Financial Stability Department, as well as ensuring that decision brought into practice in the field of financial stability are based on discussion within the meetings of the relevant Committee, reflects the implementation of best practices on institutional strengthening of central bank responsibility for macrofinancial processes. Organization of stress testing, publication of Financial Stability Reports, development of tools for analysing macrofinancial processes (building a financial stress index), etc., show the progress the NBU has already made towards the implementation of the mandate in the field of financial stability. The introduction of modern macroprudential instruments will reflect the fact that the NBU will be fully prepared for the implementation of so-called «new functions» (the content and role of «new functions» in the institutional architecture of central banks are presented in (Balls, Howart, Stansbury, 2016), the emergence of which is accompanied by the process of central bank transformation after the global financial crisis.

Describing the guidelines of the financial stability policy of Ukraine in terms of implementing macroprudential regulation, one can see the following.

Firstly, a fundamental analysis of the economic, institutional environment and nature of systemic risks requires a clear focus on the issues of systemic vulnerability of the domestic financial sector and the consideration of an entire set of institutional distortions that blur the boundary between macroprudential and micro-prudential regulation. The latter has become particularly evident in 20142015. It is also necessary to consider that the domestic economy is likely to become more dependent on fluctuations in commodity prices in the medium term. This means that financial stability will continue to remain extremely sensitive to volatile capital flows synchronized with reversals of commodity prices.

Secondly, requires a deeper understanding of the issue of system vulnerabilities generated by the activities of non-transparent financial and industrial groups, oligarchic banking, lending, and offshoring. The concentration of oligarchic groups in commodity exports combined with the practices of related lending increases the systemic vulnerability of the banking system to fluctuations in commodity prices and changes in the hryvnia exchange rate even with the formal observance of microprudential restrictions on insider lending. The same applies to systemic risks generated by offshore capital flows. In the favourable phase of the cycle, the flow of capital from offshore will confirm the desire for expansion of individual business groups, while in an unfavourable phase, the outflow of capital 

and the Guidelines for the NBU Macroprudential Policy

will reflect the fact that offshores act as «quiet harbours,» and foreign currency plays the role of "safe assets». This situation creates a risk of blurring the boundaries between macroprudential policy and policy on the regulation of capital flows.

Thirdly, the vulnerability of the domestic financial sector to changing global financial conditions requires a clearer identification. In particular, it concerns the impact the fluctuations in global liquidity and the prevailing attitude towards risks in global markets have on the propensity to external borrowing in the real and financial sector, the definition of credit standards, internal interest rates, the ability of economic agents to accumulate debt, etc. The correlation between commodity prices and capital flows as a manifestation of the situation in global liquidity requires permanent monitoring and inclusion of a standard set of indicators, the state of which is associated with intermediate targets of macroprudential policy.

Fourthly, the financial sector's vulnerability to exchange rate changes requires a clear «decomposition» of transmission channels, taking into account the pro-cyclical accumulation of corporate external debt and the motivation to do so, the risks of intermittent changes in access to global borrowing markets from the corporate sector, a rather high level of concentration of external borrowing to separate business groups. The same applies to the problem of dollarization. It needs explicit recognition as a source of macrofinancial risks, which should be addressed by macroprudential policy.

Fifthly, strategic goals for macroprudential regulation should focus on reducing the pro-cyclicality of the financial system as a source of financial instability and volatility of inflation and GDP, taking into account the conflict between maintaining liquidity of financial institutions and the exchange rate under shock. The absence of traditional "safe assets» (the vulnerability of the public debt market to the outflow of capital from it) increases the value of the exchange rate in a set of pro-cyclicality's drivers. This problem should also find the appropriate correlation in the set of intermediate goals in terms of: limiting the vulnerability of the financial system to reversals in capital flows and exchange rate changes, taking into account the significant role of balance effects in the behaviour of creditors and borrowers; limiting the vulnerability of the financial system to the direct and indirect effects of fluctuations in commodity prices. For example, this may concern the issue of concentration of lending in the sector, which in a particular period demonstrates the ability to expand. Alternatively - active lending to a non-export sector that responds to the expected increase in revenues associated with the growing export sector. In the latter case, there is a problem of blurring the boundary between macroprudential policies and macroeconomic policies that are vulnerable to the negative Balassa-Samuelson effect, coupled with structural challenges generated by caution regarding the «Dutch disease». Intermediate goals can also be supplemented by limiting the vulnerability to asset price inflation in terms of the expansion of credit and weakening credit standards, which can be combined with both commodity prices and capital inflows, and can show a 
general tendency of increasing revenue expected due to the real convergence effect.

Sixthly, the emphasis on the desire to use a minimum number of tools does not entirely correspond with the practices of macroprudential policy in economies with a significant share of commodity exports. They tend to combine a large number of diverse tools that are not only designed to limit pro-cyclicality of the financial system, the vulnerability to reverses in capital flows and commodity prices, but which are also aimed at limiting the accumulation of debt and the negative balance sheet effects outside the dominant export sector.

Seventhly, structural features of the domestic economy indicate a significant risk of blurred areas of responsibility for monetary, macroprudential, microprudential policies and capital regulation policies. The organization of coordination between these policies is considered a typical problem for macroprudential regulation (IMF-FSB-BIS, 2016; IMF, 2013). In light of the considerable sensitivity of financial stability in Ukraine to capital flows, commodity prices and significant exchange rate fluctuations, coordination between these policies should be structured much clearer and the risk of blurred boundaries between their areas of responsibility should be minimized, including through dual use of certain tools.

Eighthly, like most central banks carrying out or starting to implement «new functions» (Balls, Howart, Stansbury, 2016), the NBU faces the issue of institutionalizing its macroprudential powers. Technically, Art. 6 of the Law on the National Bank of Ukraine paves the way for the «legitimization» of using the macroprudential policy tools, often accompanied by an increase in the regulatory burden of banking activity. However, the legislation lacks the link between the tasks of promoting financial stability and the fact that these tasks are carried out on the basis of macroprudential policy, operating on the basis of specialized tools. The institutional transformation of central banks after the global financial crisis demonstrates that the delegation of macroprudential powers is done explicitly, that is, based on legislative provisions. This removes the question of the «legitimacy» of using the relevant instruments, and also guarantees that the independence of the central bank extends to macroprudential policies. Taking into account the peculiarities of the domestic economy and the political environment, the implementation of the macro-prudential policy of the NBU may potentially require institutionalization through legislative mandate of the respective powers.

\section{Conclusions}

Nearly a decade after the global financial crisis began, we may observe the changes in approaches to implementing financial stability policy. There is a growing theoretical consensus that monetary policy, responding to financial im- 

and the Guidelines for the NBU Macroprudential Policy

balances and thus threatening the increased macroeconomic volatility, needs to be complemented by specialized instruments addressed to systemic risks and the pro-cyclicality of the financial system. Macroprudential regulation has been widely recognized and is being actively introduced by many central banks. In consideration of established views on a set of macroprudential tools, their functionality and methods of application, empirical studies point to a number of controversial points: the level of financial development and the scope of regulation are important; tools addressing borrowers often work best where there are significant cross-border modulations of capital. In small open economies, macroprudential instruments also play an important role in smoothing the conflict between price, exchange rate and financial stability. Commodity economies are a vivid example of how macro-prudential regulation can reduce the systemic vulnerability of the financial system to fluctuations in resource prices. In addition, such tools allow limiting the negative Balassa-Samuelson effects, increasing the leverage in non-export sectors, thereby weakening the concentration of credit in potentially vulnerable areas. The growth of raw material dependence of Ukraine is superimposed on institutional distortions and oligarchic banking, thus opening the door to additional burden on macroprudential regulation. The concentration of risks within non-transparent business groups, the sensitivity of their expansion to commodity prices, the link between reversals in capital flows and commodity prices determine the specific profile of the macroeconomic vulnerability of the Ukrainian economy. The guidelines of the NBU macroprudential policy should include both typical pro-cyclicality manifestations, the vulnerability of financial stability to the exchange rate, as well as structural distortions in the financial sector interwoven with the vulnerability of capital flows to fluctuations in commodity prices.

\section{References}

1. Borio, C., White, W. (2004). «Whither Monetary and Financial Stability? The Implications of Evolving Policy Regims». BIS Working Paper. № 147. pp. 1-51.

2. Borio, C. (2006). «Monetary and Prudential Policies at a Crossroads? New Challenges in the New Century». BIS Working Paper. № 193. pp. 2-28.

3. Borio, C. (2006). «Monetary Policy and Financial Stability: What Role in Prevention and Recovery?» BIS Working Paper. № 440. pp. 1-23.

4. Bernanke, B., Gertler, M. (1999). «Monetary Policy and Asset Prices Volatility». Federal Reserve Bank of Kansas City Economic Review. Issue QIV, pp. 17-51. 
5. Svensson, L. (2016). "Cost-Benefits Analysis of Leaning Against the Wind: Are Costs Larger Also with Less Effective Macroprudential Policy?» IMF Working Paper. WP/16/3. pp. 1-76.

6. IMF. (2015). Monetary Policy and Financial Stability. Staff Report. - Sept. pp. 1-66.

7. Bayoumi, T., Dell'Ariccia,G., Habermeier, K. Mancini-Griffoli, T., Valencia, F. (2014). "Monetary Policy in the New Normal». IMF Staff Discussion Note. SDN/14/3. pp. 1-48.

8. IMF-FSB-BIS. (2016). «Elements of Effective Macroprudential Policies. Lessons from International Expirience». 26 Augest 2016. pp. 1-22.

9. IMF. (2013). "Key Aspects of Macroprudential Policy - Background Paper». IMF Policy Paper. June. pp. 1-68.

10. IMF. (2013). «Key Aspects of Macroprudential Policy». IMF Policy Paper. June. pp. 1-56.

11. IMF. (2013). "The Interaction of Monetary and Macroprudential Policy». IMF Policy paper. January. pp. 1-48.

12. CGFS. (2010). "Macroprudential Instruments and Frameworks: A Stocktaking of Issues and Experience». CGFS Paper. № 38 (Basel: BIS). pp. 1-46.

13. Claessens, S. (2014). «An Overview of Macroprudential Policy Tools». IMF Working Paper. WP/14/214. pp. 37.

14. Cerutti, E., Correa, R., Fiorentino, E., Segalla, E. (2016). «Changes in Prudential Policy Instruments - A New Cross-Country Database». IMF Working Paper. WP/16/110. pp. 1-23.

15. Bruno, V., Shim, I., Song Shin, H. (2015). "Comparative Assessment of Macroprudential Policies». BIS Working Paper № 502. pp. 1-56.

16. Cerutti, E., Claessens, S., Laeven, L. (2015). "The Use and Effectiveness of Macroprudential Policies: New Evidence». IMF Working Paper. WP/15/61. pp. 1-36.

17. Carreras, O., Davis, Ph., Piggot, R. (2016). «Macroprudential Tools, Transmission and Modelling». Firstrun Deliverable 4.7. pp. 1-57.

18. Cizel, J., Frost, J., Houben, A., Wierts, P. (2016). «Effective Macroprudential Policy: Cross-Sectors Substitution from Price and Quantity Measures». IMF Working Paper. WP/16/94. pp. 1-47.

19. Gulcin Ozkan, F., Filiz Unsal, D. (2014). "On the Use of Monetary and Macroprudential Policies for Small Open Economies». IMF Working Paper. WP/14/112. pp. 1-26.

20. Turner, Ph. (2016). «Macroprudential Policies, the Long-term Interest Rate and the Exchange Rate». BIS Working Paper № 588. pp. 1-23. 
21. Kurronen, S. (2012). «Financial Sector in Resource-Dependent Economies». BOFIT Discussion Papers. 2012.6. - pp. 1-35.

22. Masson, P. (2014). «Macroprudential Policies, Commodity Prices and Capital Inflows». BIS Papers № 76. pp. 59-75.

23. Alberola, E., Benigno, G. (2017). «Revisiting the Commodity Curse: A Financial Perspective». BIS Working Papers. № 609. pp. 1-55.

24. Gonzalez, A., Hamann, F., Rodriguez, D. (2015). «Macroprudential Policies in Commodity Exporting Economy». BIS Papers № 86. pp. 69-73.

25. IMF-GCC. (2015). «Oil Prices, Financial Stability, and the Use of Countercyclical Macroprudential Policies in the GCC». Annual Meeting of Ministers of Finance and Central Bank Governors. Nov. 10, 2015. Doha, Qatar. (IMF: Staff Paper). pp. 1-30.

26. Koziuk, V. (2016). «Independence of Central Banks in Commodity Economies». Gerald of National Bank of Ukraine. March. pp. 6-25.

27. Aizenman, J., Noy, I. (2011). Inflation Targeting and Real Exchange Rates in Emerging Markets. World Development. Vol. 39. № 5. pp. 712-724.

28. IMF. 2015. "Where Are Commodity Exporters Headed? Output Growth in the Aftermath of the Commodity Boom». World Economic Outlook. October. 2015. Chapter 2.

29. Jimenez, G., Ongena, S., Peydro, J.-L., Saurina Salas J. 2012. «Macroprudential Policy, Countercyclical Bank Capital Buffers and Credit Supply: Evidence from Spanish Dynamic Provisioning Experiments». European Banking Center Discussion Paper 2012-011.

30. Zhang, L., Zoli, E. 2014. «Leaning Against the Wind: Macroprudential Policy in Asia». IMF Working Paper. WP/14/22. pp. 34.

31. Balls, Ed, Howart, J., Stansbury, A. (2016). "Central Bank Independence Revisited: After the Financial Crisis, What Should a Model Central Bank Look Like?» Mossavar-Rahmani Center for Business and Government Working Paper. Nov. № 67. pp. 1-113 